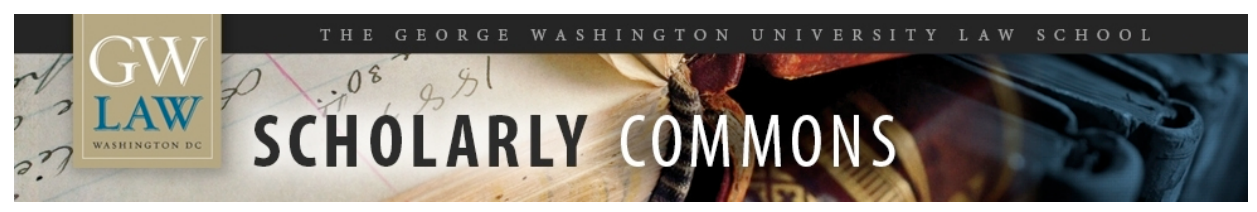

\title{
Protection of Persons in the Event of Disasters and Other Topics: The Sixty-Eighth Session of the International Law Commission
}

\author{
Sean D. Murphy
}

George Washington University Law School, smurphy@law.gwu.edu

Follow this and additional works at: https://scholarship.law.gwu.edu/faculty_publications

Part of the Law Commons

\section{Recommended Citation}

Murphy, Sean D., Protection of Persons in the Event of Disasters and Other Topics: The Sixty-Eighth Session of the International Law Commission (2016). Forthcoming in the American Journal of International Law (October 2016); GWU Law School Public Law Research Paper No. 2016-51; GWU Legal Studies Research Paper No. 2016-51. Available at SSRN: http://ssrn.com/abstract=2848992

This Article is brought to you for free and open access by the Faculty Scholarship at Scholarly Commons. It has been accepted for inclusion in GW Law Faculty Publications \& Other Works by an authorized administrator of Scholarly Commons. For more information, please contact spagel@law.gwu.edu. 


\title{
CURRENT DEVELOPMENTS
}

\section{Protection of Persons in the Event of Disasters AND Other ToPics: THE SIXTY-EIGHTH SESSION OF THE INTERNATIONAL LAW COMMISSION}

\author{
By Sean D. Murphy*
}

The International Law Commission held its sixty-eighth session in Geneva from May 2 to June 10, and from July 4 to August 12, 2016, under the chairmanship of Pedro Comissário Afonso (Mozambique). ${ }^{1}$ Notably, the Commission completed on second reading a full set of eighteen draft articles with commentary on the protection of persons in the event of disasters and recommended to the United Nations General Assembly that it elaborate a convention based on the draft articles.

Additionally, the Commission adopted on first reading a complete set of draft conclusions, with commentary, for two topics: identification of customary international law; and subsequent agreements and subsequent practice in relation to the interpretation of treaties. As such, both topics might be completed by the Commission on second reading in 2018.

Progress was also made in developing draft articles on crimes against humanity; draft guidelines on protection of the atmosphere; draft conclusions on jus cogens; and draft principles on protection of the environment in relation to armed conflicts. The Commission commenced a debate on a proposed draft article on "limitations and exceptions" to the immunity of state officials from foreign criminal jurisdiction, but, due to insufficient time, the debate will continue in 2017. Furthermore, an additional proposed guideline on the provisional application of treaties was sent to the drafting committee. The Commission decided to add two new topics to its longterm work program: the settlement of international disputes to which international organizations are parties; and succession of states in respect of state responsibility.

\section{Protection of Persons in the Event of Disasters}

In 2008, the Commission commenced work on the topic of the protection of persons in the event of disasters and thereafter was guided by eight reports submitted by the special rapporteur, Eduardo Valencia-Ospina (Colombia). ${ }^{2}$ As a general matter, the topic seeks to set

\footnotetext{
* Patricia Roberts Harris Research Professor of Law, George Washington University, and member of the UN International Law Commission.

${ }^{1}$ See Report of the International Law Commission on the Work of Its Sixty-Eighth Session, UN GAOR, 71st Sess., Supp. No. 10, at 2, para. 3, UN Doc. A/71/10 (Sept. 19, 2016) [hereinafter 2016 Report]. This report and other ILC documents are available online at http://legal.un.org/ilc. In addition, UN documents are generally available online at https://documents.un.org/prod/ods.nsf/home.xsp.

${ }^{2}$ International Law Commission, Eighth Report on the Protection of Persons in the Event of Disasters, UN Doc. A/CN.4/697 (Mar. 17, 2016) (prepared by Special Rapporteur Eduardo Valencia-Ospina). For discussion of prior
} 
forth relevant principles and rules of international law applicable with respect to a disaster, defined as "a calamitous event or series of events resulting in widespread loss of life, great human suffering and distress, mass displacement, or large-scale material or environmental damage, thereby seriously disrupting the functioning of society."3

During the sixty-eighth session, the Commission completed on second reading a full set of eighteen draft articles, with commentaries, on this topic. ${ }^{4}$ To accompany the draft articles, the Commission adopted a preamble, containing a final clause that sets the tone for the draft articles by stressing the sovereignty of states, but at the same time reaffirming that with such sovereignty comes the "the primary role of the State affected by a disaster in providing disaster relief assistance." The draft articles then proceed to identify various duties for such states and for those entities in a position to assist them.

The preamble notes the role of the General Assembly in encouraging the progressive development of international law and its codification in relation to disasters. The Commission's commentary to that clause indicates that it "serves, at the outset, to highlight the fact that the draft articles contain elements of both progressive development and codification of international law." 6 Thereafter, however, the commentary does not distinguish between those elements that are progressive development and those that are codification, such that it remains unspecified as to what extent the draft articles are intended to restate customary international law or, instead, to advance the preferences of the Commission as to what the law should be.

Perhaps due to a belief that significant aspects of the draft articles represent progressive development of the law, the Commission recommended, in accordance with Article 23 of its Statute, ${ }^{7}$ that the General Assembly elaborate a convention on the basis of the draft articles. ${ }^{8}$ Whether the General Assembly will do so depends on many factors, including whether states (particularly states typically involved in transnational relief operations) are willing to assume or acknowledge the "duties" set forth in the draft articles. The written and oral comments received by the Commission from states based on the outcome of the first reading of the draft articles

\footnotetext{
work on these draft articles, see Sean D. Murphy, The Expulsion of Aliens and Other Topics: The Sixty-Fourth Session of the International Law Commission, 107 AJIL 164, 168-69 (2013) [hereinafter Murphy, Sixty-Fourth Session]; Sean D. Murphy, Immunity Ratione Personae of Foreign Government Officials and Other Topics: The Sixty-Fifth Session of the International Law Commission, 108 AJIL 41, 51-52 (2014) [hereinafter Murphy, SixtyFifth Session]; Sean D. Murphy, The Expulsion of Aliens (Revisited) and Other Topics: The Sixty-Sixth Session of the International Law Commission, 109 AJIL 125, 132-35 (2015) [hereinafter Murphy, Sixty-Sixth Session]; Sean D. Murphy, Identification of Customary International Law and Other Topics: The Sixty-Seventh Session of the International Law Commission, 109 AJIL 822, 843-44 (2015) [hereinafter Murphy, Sixty-Seventh Session]. 32016 Report, supra note 1, at 21 (draft Article 3(a)).

${ }^{4}$ Id. at $17-73$, para. 49.

${ }^{5} \mathrm{Id}$. at 17 , pmbl.

${ }^{6} \mathrm{Id}$. at $17-18$.

${ }^{7}$ Statute of the International Law Commission, Art. 23, GA Res. 174 (II) (Nov. 21, 1947).

${ }^{8} 2016$ Report, supra note 1 , at 13, para. 46.
} 
suggest various important concerns, not all of which were addressed by the Commission at the second reading.

For example, draft Article 7 on the "duty to cooperate" provides that "States shall, as appropriate, cooperate among themselves, with the United Nations, with the components of the Red Cross and Red Crescent Movement, and with other assisting actors."9 After the first reading, many states expressed concern as to whether such a "duty to cooperate" existed under international law. For example, Greece noted that the use of mandatory language in the form of "shall" was not supported by state practice, ${ }^{10}$ a concern echoed by the Nordic states ${ }^{11}$ and Austria. ${ }^{12}$ The Russian Federation maintained that the duty in the draft article was not a wellestablished principle of international law. ${ }^{13}$ The United Kingdom viewed that recourse to “"rights' and 'duties' used in the draft articles" was at odds with the voluntary nature of the principle of cooperation. ${ }^{14}$ Whether the Commission's commentary ultimately helps to persuade states to accept or acknowledge such a duty remains to be seen. The commentary to draft Article 7 relies in part on provisions concerning general interstate cooperation, such as those contained in the UN Charter ${ }^{15}$ and in the General Assembly's 1970 Declaration on Friendly Relations, ${ }^{16}$ but those instruments do not speak directly to disaster relief operations or to cooperation with nonstate actors. The commentary also relies on the General Assembly's 1991 resolution "Strengthening of the Coordination of Humanitarian Emergency Assistance of the United Nations," but that resolution uses "should" rather than "shall" when speaking of such cooperation. $^{17}$

Likewise, draft Article 9, paragraph 1, advances a duty to reduce the risk of disasters: "Each State shall reduce the risk of disasters by taking appropriate measures, including through legislation and regulations, to prevent, mitigate, and prepare for disasters." 18 This language, too, elicited negative reactions from many states who disputed that international law obliges states to reduce the risk of disasters. For example, France, ${ }^{19}$ the Republic of Korea, ${ }^{20}$ and the United

\footnotetext{
${ }^{9}$ Id. at 53.

${ }^{10}$ UN GAOR, 67th Sess., 19th mtg. at 10, para. 58, UN Doc. A/C.6/67/SR.19 (Dec. 4, 2012).

${ }^{11}$ UN GAOR, 67th Sess., 18th mtg. at 9, para. 53,UN Doc. A/C.6/67/SR.18 (Dec. 4, 2012).

${ }^{12} I d$. at 14 , para. 88.

${ }^{13}$ UN GAOR, 68th Sess., 25th mtg. at 8, para. 38, UN Doc. A/C.6/68/SR.25 (Dec. 2, 2013).

${ }^{14}$ UN Doc. A/C.6/67/SR.19, supra note 10, para. 65.

${ }^{15}$ UN Charter, Arts. 1(3), 55, 56.

${ }^{16}$ Declaration on Principles of International Law Concerning Friendly Relations and Co-operation Among States in Accordance with the Charter of the United Nations, GA Res. 2625 (XXV), annex (Oct. 24, 1970).

${ }^{17}$ Strengthening of the Coordination of Humanitarian Emergency Assistance of the United Nations, GA Res. 46/182, annex, para. 5 (Dec. 19, 1991) ("The magnitude and duration of many emergencies may be beyond the response capacity of many affected countries. International cooperation to address emergency situations and to strengthen the response capacity of affected countries is thus of great importance. Such cooperation should be provided in accordance with international law and national laws. Intergovernmental and non-governmental organizations working impartially and with strictly humanitarian motives should continue to make a significant contribution in supplementing national efforts.").

182016 Report, supra note 1 , at 42.

${ }^{19}$ UN GAOR, 68th Sess., 17th mtg. at 19, para. 113, UN Doc. A/C.6/68/SR.17 (Nov. 8, 2013).
} 
States $^{21}$ all said that there is no general obligation under international law to take measures to prevent, mitigate, and prepare for disasters, while Austria even asserted that this issue exceeded the Commission's mandate for work on this topic. ${ }^{22}$ Still other states, such as Australia ${ }^{23}$ and South Africa, ${ }^{24}$ expressed concerns as to whether states had the capacity or resources to take such measures, leading the Russian Federation to propose that a qualifier of "within their capacity" be added. ${ }^{25}$ The Russian Federation also proposed that this draft article be framed instead as a recommendation, ${ }^{26}$ but the Commission chose not to do so.

Draft Article 10, paragraph 1, provides that the "affected State has the duty to ensure the protection of persons and provision of disaster relief assistance in its territory, or in territory under its jurisdiction or control." 27 The Commission's commentary asserts that this "duty" is premised on "the core principle of sovereignty," meaning that the state's entitlement to sovereignty carries with it certain obligations to persons within its territory. ${ }^{28}$ The commentary notes that the "Commission considered that the term 'duty' was more appropriate than the term 'responsibility,' which could be misunderstood given its use in other contexts." ${ }^{29}$ In this regard, it should be noted that the Commission had previously decided that the "responsibility to protect" (R2P) concept did not apply in the context of disaster relief. ${ }^{30}$ Yet, even so, not all states appear to agree that even such a "duty" exists; Russia maintained that, while a state has a general responsibility to take measures to ensure the protection of persons on its territory, it did not have a legal obligation to do so. ${ }^{31}$

${ }^{20}$ UN GAOR, 68th Sess., 24th mtg. at 14, para. 91, UN Doc. A/C.6/68/SR.24 (Nov. 20, 2013).

${ }^{21}$ UN GAOR, 68th Sess., 23d mtg. at 11, para. 48, UN Doc. A/C.6/68/SR.23 (Dec. 5, 2013); UN GAOR, 69th Sess., 20th mtg. at 19, para. 120, UN Doc. A/C.6/69/SR.20 (Nov. 10, 2014) (referring to draft Article 11, which was subsequently renumbered as draft Article 9).

${ }^{22}$ UN Doc. A/C.6/68/SR.23, supra note 21, at 14, para. 63. Austria appears to have interpreted the original mandate as focusing only on post-disaster responses and not on pre-disaster measures relating to prevention, mitigation, and preparation.

${ }^{23}$ Protection of Persons in the Event of Disasters, Comments and Observations Received from Governments and International Organizations, at 38, UN Doc. A/CN.4/696 (Mar. 14, 2016).

${ }^{24}$ UN Doc. A/C.6/68/SR.24, supra note 20, at 3, para. 15.

${ }^{25}$ UN Doc. A/C.6/68/SR.25, supra note 13, at 8, para. 41 (referring to draft Article 16, which was subsequently renumbered as draft Article 9); UN GAOR, 69th Sess., 19th mtg. at 14, para. 105, UN Doc. A/C.6/69/SR.19 (Nov. 17, 2014).

${ }^{26}$ UN Doc. A/C.6/68/SR.25, supra note 13, at 8, para. 41; UN Doc. A/C.6/69/SR.19, supra note 25, at 14, para. 105. ${ }^{27} 2016$ Report, supra note 1, at 50 (draft Article 10(1)).

${ }^{28} I d$. at 51 .

${ }^{29} \mathrm{Id}$. at 52 .

${ }^{30}$ See Report of the International Law Commission on the Work of Its Sixty-First Session, UN GAOR, 64th Sess., Supp. No. 10, at 335, para. 156, UN Doc. A/64/10 (2016) ('As regards the concept of 'responsibility to protect,' the Special Rapporteur recalled the 2009 report of the Secretary-General on implementing the responsibility to protect, which clarified that the concept did not apply to disaster response."); id. at 338, para. 164 ("Agreement was expressed with the Special Rapporteur's conclusions on the non-applicability of the concept of responsibility to protect....").

${ }^{31}$ UN GAOR, 65th Sess., 23d mtg. at 9, para. 58, UN Doc. A/C.6/65/SR.23 (Dec. 1, 2010). 
Draft Article 11 asserts that "[ $\mathrm{t}] \mathrm{o}$ the extent that a disaster manifestly exceeds its national response capacity, the affected State has the duty to seek assistance from, as appropriate, other States, the United Nations, and other potential assisting actors." 32 Here, too, numerous states rejected the idea that there was a "duty" under international law for an affected state to seek assistance. For example, Austria, ${ }^{33}$ France, ${ }^{34}$ Indonesia, ${ }^{35}$ Malaysia, ${ }^{36}$ Russia, ${ }^{37}$ and the United Kingdom $^{38}$ all expressed the view that no such duty existed. Other states, including Austria, ${ }^{39}$ Poland, ${ }^{40}$ and Russia, ${ }^{41}$ queried as to what would be the consequences of a breach of this duty. China suggested that the Commission avoid the term "duty," 42 and Iran suggested rephrasing the draft article to read that the affected state "should" seek assistance. ${ }^{43}$ Even so, the text remained essentially unchanged on second reading. ${ }^{44}$

Draft Article 13 provides in paragraph 1 that the "provision of external assistance requires the consent of the affected State," but paragraph 2 asserts that "[c]onsent to external assistance shall not be withheld arbitrarily." 45 Several states, in their comments to the Commission, rejected the idea of a legal obligation under customary international law not to withhold consent arbitrarily. ${ }^{46}$ Other states sought additional clarification on the meaning of "arbitrarily" and on who would determine if a state's decision to withhold aid was arbitrary. ${ }^{47}$ Still others worried that if the consent was withheld arbitrarily, then the draft article might be

${ }^{32} 2016$ Report, supra note 1, at 53 (draft Article 11).

${ }^{33}$ UN GAOR, 66th Sess., 23d mtg. at 5, para. 23, UN Doc. A/C.6/66/SR.23 (Nov. 14, 2011).

${ }^{34} \mathrm{Id}$. at 9 , para. 38 .

${ }^{35}$ UN GAOR, 66th Sess., 24th mtg. at 13, para. 70,UN Doc. A/C.6/66/SR.24 (Dec. 1, 2011).

${ }^{36} I d$. at 20, para. 114.

${ }^{37} \mathrm{Id}$. at 7 , para. 37.

${ }^{38}$ UN Doc. A/C.6/66/SR.23, supra note 33, at 10, para. 45.

${ }^{39}$ UN Doc. A/CN.4/696, supra note 23, at 40-41 (referring to draft Article 13, which was subsequently renumbered as draft Article 11).

${ }^{40}$ UN Doc. A/C.6/67/SR.19, supra note 10, at 12, para. 73 (referring to draft Article 10, which was subsequently renumbered as draft Article 11).

${ }^{41}$ UN Doc. A/C.6/69/SR.19, supra note 25, at 14, para. 107.

${ }^{42}$ UN Doc. A/C.6/69/SR.20, supra note 21, at 5, para. 25.

${ }^{43}$ UN Doc. A/C.6/66/SR.24, supra note 35, at 10, para. 50; UN GAOR, 67th Sess., 20th mtg. at 3, para. 14, UN Doc. A/C.6/67/SR.20 (Dec. 7, 2012).

${ }^{44}$ The text at first reading provided: "To the extent that a disaster exceeds its national response capacity, the affected State has the duty to seek assistance from among other States, the United Nations, other competent intergovernmental organizations and relevant non-governmental organizations, as appropriate." Report of the International Law Commission on the Work of Its Sixty-Sixth Session, UN GAOR, 69th Sess., Supp. No. 10, at 119, UN Doc. A/69/10 (2014) [hereinafter 2014 Report].

${ }^{45} 2016$ Report, supra note 1, at 59 (draft Article 13).

${ }^{46}$ See, e.g., UN Doc. A/CN.4/696, supra note 23, at 43 (Australia) (referring to draft Article 14, which was subsequently renumbered as draft Article 13); UN Doc. A/C.6/66/SR.23, supra note 33, at 10, para. 42 (China) (referring to draft Article 11, which was subsequently renumbered as draft Article 13).

${ }^{47}$ UN Doc. A/C.6/66/SR.23, supra note 33, at 8, para. 33 (Israel); UN GAOR, 66th Sess., 25th mtg. at 3, para. 10, UN Doc. A/C.6/66/SR.25 (Dec. 9, 2011) (Argentina) (referring to draft Article 11, which was subsequently renumbered as draft Article 13); UN Doc. A/C.6/67/SR.20, supra note 43, at 4, para. 20 (India). Other states sought clarification as to who would decide if an arbitrary refusal of consent occurred. E.g., UN GAOR, 66th Sess., 24th mtg. at 20, para. 118, UN Doc. A/C.6/66/SR/24 (Dec. 1, 2011) (Malaysia); UN Doc. A/C.6/66/SR.25, supra, at 4, para. 22 (Ireland). 
read as allowing other states to act without the affected state's consent, ${ }^{48}$ or at least to pass judgments upon the affected state. ${ }^{49}$ For such reasons, some states suggested that the draft article in some fashion be expressed as a political or moral recommendation. ${ }^{50}$ The text, however, remained unchanged on second reading. A further issue, unaddressed in this text, is whether disaster assistance can be provided in circumstances where the disaster has resulted in a collapse of the affected state's government, such that consent is not possible.

One important question not fully resolved by the text adopted at first reading concerned the relationship of these draft articles to other rules of international law, notably those that apply during an armed conflict. Treaties on the law of armed conflict contain numerous provisions that balance the rights and duties of a belligerent, in the specific situation of armed conflict, with respect to relief activities, including consignments of medical supplies, food and clothing, cooperation with national Red Cross and other societies, and treatment of relief personnel. ${ }^{51}$ Draft Article 18 announces in paragraph 1 that the "present draft articles are without prejudice to other applicable rules of international law" and in paragraph 2 that they "do not apply to the extent that the response to a disaster is governed by the rules of international humanitarian law.",52

\section{COMPLETION OF THE FIRST READING FOR TwO TOPICS}

\section{Identification of Customary International Law}

At the sixty-eighth session, the Commission debated the fourth report of the special rapporteur Michael Wood (United Kingdom) on the identification of customary international law. ${ }^{53}$ This report proposed a few revisions to the set of sixteen draft conclusions on this topic previously adopted by the drafting committee. ${ }^{54}$ Until this session, the work on this topic had

\footnotetext{
${ }^{48}$ UN Doc. A/CN.4/696, supra note 23, at 40-41 (Austria); see also id. at 44 (Germany) ("We concur that although the consent of the affected State shall not be withheld arbitrarily, consent is nevertheless an indispensable requirement for every provision of external assistance.") (referring to draft Article 14, which was subsequently renumbered as draft Article 13).

${ }^{49} \mathrm{UN}$ Doc. A/C.6/66/SR.24, supra note 35, at 10, para. 52 (Iran).

${ }^{50}$ See, e.g., UN Doc. A/C.6/66/SR.24, supra note 35, at 7, para. 37 (Russia).

${ }^{51}$ See, e.g., Geneva Convention [No. IV] Relative to the Protection of Civilian Persons in Time of War, Arts. 23, 55, 59-63, 109-11, Aug. 12, 1949, 6 UST 3516, 75 UNTS 287; Protocol Additional to the Geneva Conventions of 12 August 1949, and Relating to the Protection of Victims of International Armed Conflicts, Arts. 69-71, June 8, 1977, 1125 UNTS 3, 16 ILM 1391 (1977); Protocol Additional to the Geneva Conventions of 12 August 1949, and Relating to the Protection of Victims of Non-international Armed Conflicts, Art. 18, June 8, 1977, 1125 UNTS 609. ${ }_{53}^{52} 2016$ Report, supra note 1, at 72 (draft Article 18).

${ }^{53}$ International Law Commission, Fourth Report on Identification of Customary International Law, UN Doc. A/CN.4/695 (Mar. 8, 2016) (prepared by Special Rapporteur Michael Wood); see also Fourth Report on Identification of Customary International Law, Addendum, UN Doc. A/CN.4/695/Add.1 (May 25, 2016) (extensive bibliography on the topic).

${ }^{54}$ For discussion of prior work on these draft conclusions, see Murphy, Sixty-Fourth Session, supra note 2, at 174; Murphy, Sixty-Fifth Session, supra note 2, at 52-53; Murphy, Sixty-Sixth Session, supra note 2, at 140-42; Murphy, Sixty-Seventh Session, supra note 2, at 822-32.
} 
remained in the drafting committee, without piecemeal adoption by the Commission of draft conclusions with commentary. As such, the Commission's principal work on this topic during this session was to consider and revise the commentary proposed by Wood to the entire set of draft conclusions, which was done first in a specially convened working group and then in the plenary. The Commission subsequently adopted, on first reading, the draft conclusions with commentary. 55

The opening paragraphs of the commentary state:

(1) The present draft conclusions concern the methodology for identifying rules of customary international law. They seek to offer practical guidance on how the existence (or non-existence) of rules of customary international law, and their content, are to be determined. This matter is not only of concern to specialists in public international law; others, including those involved with national courts, are increasingly called upon to apply or advise on customary international law. Whenever doing so, a structured and careful process of legal analysis and evaluation is required to ensure that a rule of customary international law is properly identified, thus promoting the credibility of the particular determination.

(2) Customary international law remains an important source of public international law. In the international legal system, such unwritten law, deriving from practice accepted as law, can be an effective means for subjects of international law to regulate their behaviour and it is indeed often invoked by States and others. Customary international law is, moreover, among the sources of international law listed in Article 38, paragraph 1, of the Statute of the International Court of Justice, which refers, in subparagraph (b), to "international custom, as evidence of a general practice accepted as law." This wording reflects the two constituent elements of customary international law: a general practice and its acceptance as law (also referred to as opinio juris).

(3) The identification of customary international law is a matter on which there is a wealth of material, including case law and scholarly writings. The draft conclusions reflect the approach adopted by States, as well as by international courts and tribunals and within international organizations. Recognizing that the process for the identification of customary international law is not always susceptible to exact formulations, they aim to offer clear guidance without being overly prescriptive.

(4) The 16 draft conclusions that follow are divided into seven parts. Part One deals with scope and purpose. Part Two sets out the basic approach to the identification of customary international law, the "two element" approach. Parts Three and Four provide

${ }^{55} 2016$ Report, supra note 1 , at 80-117. 
further guidance on the two constituent elements of customary international law, which also serve as the criteria for its identification, "a general practice" and "acceptance as law" (opinio juris). Part Five addresses certain categories of materials that are frequently invoked in the identification of rules of customary international law. Parts Six and Seven deal with two exceptional cases: the persistent objector; and particular customary international law (being rules of customary international law that apply only among a limited number of States). ${ }^{56}$

Having completed the first reading on this topic, the Commission will now wait for comments from states and others, with a likely second reading in $2018 .^{57}$ Those comments may provide interesting insights into the views of states with respect to the following topics: the "twoelement" approach; the role of specially affected states; inaction as a form of state practice (and evidence of acceptance as law); the role of international organizations, as such, when identifying customary international law; the effects of treaties or resolutions of international organizations when identifying customary international law; the persistent-objector rule; and particular (regional or "special") customary international law. In the meantime, the Commission has "requested the Secretariat to prepare a memorandum on ways and means for making the evidence of customary international law more readily available, which would survey the present state of the evidence of customary international law and make suggestions for its improvement."

\section{Subsequent Agreements and Subsequent Practice in Relation to the Interpretation of Treaties}

The topic of "subsequent agreements and subsequent practice in relation to the interpretation of treaties," originally considered by a study group of the Commission within the broader topic "Treaties over Time," is now being addressed through a special rapporteur, Georg Nolte (Germany). ${ }^{59}$ Under his guidance, the Commission has developed thirteen draft conclusions on the use of subsequent agreements and subsequent practice as a means of treaty interpretation, based on the Vienna Convention on the Law of Treaties (VCLT). ${ }^{60}$

\footnotetext{
${ }^{56}$ Id. at 79-80 (footnotes omitted).

${ }^{57}$ For comments already received from states, see International Law Commission, Analytical Guide to the Work of the International Law Commission, Identification of Customary International Law (Aug. 16, 2016), at http://legal.un.org/ilc/guide/1_13.shtml.

582016 Report, supra note 1, at 75, para. 56.

${ }^{59}$ For discussion of prior work on this topic, see Murphy, Sixty-Fourth Session, supra note 2, at 176; Murphy, SixtyFifth Session, supra note 2, at 48-51; Murphy, Sixty-Sixth Session, supra note 2, at 136-38; Murphy, Sixty-Seventh Session, supra note 2, at 836-38.

${ }^{60}$ Vienna Convention on the Law of Treaties, May 23, 1969, 1155 UNTS 331, 8 ILM 679 (1969) [hereinafter VCLT].
} 
At the sixty-eighth session, the Commission first focused on the adoption of what was later numbered as draft Conclusion 13, based on a proposal in the fourth report of the special rapporteur. ${ }^{61}$ This draft conclusion, "Pronouncements of Expert Treaty Bodies," states:

1. For the purposes of these draft conclusions, an expert treaty body is a body consisting of experts serving in their personal capacity, which is established under a treaty and is not an organ of an international organization.

2. The relevance of a pronouncement of an expert treaty body for the interpretation of a treaty is subject to the applicable rules of the treaty.

3. A pronouncement of an expert treaty body may give rise to, or refer to, a subsequent agreement or subsequent practice by parties under article 31, paragraph 3 , or other subsequent practice under article 32 . Silence by a party shall not be presumed to constitute subsequent practice under article 31, paragraph 3 (b), accepting an interpretation of a treaty as expressed in a pronouncement of an expert treaty body.

4. This draft conclusion is without prejudice to the contribution that a pronouncement of an expert treaty body may otherwise make to the interpretation of a treaty. $^{62}$

Paragraph 3 is the core aspect of this draft conclusion. In its commentary to this paragraph, the Commission explains:

(9) A pronouncement of an expert treaty body cannot as such constitute subsequent practice under article 31, paragraph 3 (b), since this provision requires a subsequent practice of the parties that establishes their agreement regarding the interpretation of the treaty. This has been confirmed, for example, by the reaction to a draft proposition of the Human Rights Committee according to which its own "general body of jurisprudence," or the acquiescence by States to that jurisprudence, would constitute subsequent practice under article 31, paragraph 3 (b). The proposition of the Human Rights Committee was:

"In relation to the general body of jurisprudence generated by the Committee, it may be considered that it constitutes 'subsequent practice in the application of the treaty which establishes the agreement of the parties regarding

\footnotetext{
${ }^{61} 2016$ Report, supra note 1, at 119, para. 70 (citing International Law Commission, Fourth Report on Subsequent Agreements and Subsequent Practice in Relation to the Interpretation of Treaties, at 5-36, paras. 10-94, UN Doc. A/CN.4/694 (Mar. 7, 2016) (prepared by Special Rapporteur Georg Nolte)). The fourth report's original proposal for this draft conclusion was numbered draft Conclusion 12. The fourth report also proposed a draft Conclusion 13 on "decisions of domestic courts," which ultimately was not referred to the drafting committee.

${ }^{62}$ Id. at 123 (draft Article 13).
} 
its interpretation' within the sense of article 31(3)(b) of the Vienna Convention on the Law of Treaties, or, alternatively, the acquiescence of States parties in those determinations constitutes such practice."

(10) When this proposition was criticized by some States, the Committee did not pursue its proposal and adopted its general comment No. 33 without a reference to article 31, paragraph 3 (b). This confirms that pronouncements of expert treaty bodies cannot as such constitute subsequent practice under article 31, paragraph 3 (b).

(11) Pronouncements of expert treaty bodies may, however, give rise to, or refer to, a subsequent agreement or a subsequent practice by the parties which establish their agreement regarding the interpretation of the treaty under article 31, paragraph 3 (a) or (b). This possibility has been recognized by States, by the Commission and also by the International Law Association and by a significant number of authors. There is indeed no reason why a subsequent agreement between the parties or subsequent practice that establishes the agreement of the parties themselves regarding the interpretation of a treaty could not arise from, or be referred to by, a pronouncement of an expert treaty body.

(12) Whereas a pronouncement of an expert treaty body can, in principle, give rise to a subsequent agreement or a subsequent practice by the parties themselves under article 31 , paragraph 3 (a) and (b), this result is not easily achieved in practice. Most treaties that establish expert treaty bodies at the universal level have many parties. It will often be difficult to establish that all parties have accepted, explicitly or implicitly, that a particular pronouncement of an expert treaty body expresses a particular interpretation of the treaty. ${ }^{63}$

The commentary then proceeds to provide some examples illustrating this phenomenon and emphasizes why acceptance of a treaty interpretation should not be presumed from the silence by states parties after a pronouncement by an expert treaty body. ${ }^{64}$

Paragraph 4 of draft Conclusion 13 indicates that the draft conclusion is "without prejudice to the contribution that a pronouncement of an expert treaty body may otherwise make to the interpretation of a treaty." ${ }^{, 65}$ The commentary explains that some members considered the pronouncements of expert treaty bodies as a form of practice that may contribute to the interpretation of a treaty, while others considered any such pronouncements were not "a form of practice" in the sense of the present topic. ${ }^{66}$

\footnotetext{
${ }^{63} 2016$ Report, supra note 1, at 233-34 (footnotes omitted).

${ }^{64} \mathrm{Id}$. at $234-37$.

${ }^{65} I d$. at 229.

${ }^{66}$ Id. at $239-40$.
} 
Having completed work on draft Conclusion 13, the Commission then revisited all the draft conclusions and commentary so as to adopt them on first reading. ${ }^{67}$ The Commission now awaits comments from states and others, with a likely second reading in 2018.

\section{OTHER TOPICS ADDRESSED DURING THE SIXTY-EIGHTH SESSION}

\section{Crimes Against Humanity}

The Commission commenced work on the topic of crimes against humanity in 2014 , appointing Sean D. Murphy (United States; the present author) as special rapporteur. ${ }^{68}$ The syllabus for the topic provides that the objective is "to draft articles for what would become a Convention on the Prevention and Punishment of Crimes against Humanity." 69 At the sixtyseventh session, the Commission approved four draft articles with commentary. ${ }^{70}$ At the sixtyeighth session, the Commission debated the special rapporteur's second report ${ }^{71}$ and then referred six further draft articles-draft Articles 5, 6, 7, 8, 9, and 10 - to the drafting committee. Ultimately, the Commission approved these six draft articles with commentaries. ${ }^{72}$

Draft Article 5 sets forth various measures that each state must take under its criminal law to ensure that crimes against humanity, as such, constitute offenses, including instances when a natural person commits, attempts to commit, assists in, or contributes to a crime against humanity. ${ }^{73}$ The draft article also obligates states to ensure that command or superior responsibility exists with respect to crimes against humanity, ${ }^{74}$ in terms almost identical to those found in Rome Statute Article 28. ${ }^{75}$ Further, draft Article 5 precludes the use of any superior orders defense or any statute of limitation and requires states to provide for appropriate penalties commensurate with the grave nature of such crimes. ${ }^{76}$ Finally, draft Article 5 also provides that "[s]ubject to the provisions of its national law, each State shall take measures, where appropriate,

\footnotetext{
${ }^{67}$ Id. at $123-240$, para. 76.

682014 Report, supra note 44, at 265, para. 266. For discussion of prior work on these draft articles, see Murphy, Sixty-Seventh Session, supra note 2, at 835-36.

${ }^{69}$ See Report of the International Law Commission on the Work of Its Sixty-Fifth Session, UN GAOR, 68th Sess., Supp. No. 10, at 140, para. 3 (Annex B), UN Doc. A/68/10 (2013).

${ }^{70}$ Report of the International Law Commission on the Work of Its Sixty-Seventh Session, UN GAOR, 70th Sess., Supp. No. 10, at 50-52, UN Doc. A/70/10 (2015).

${ }^{71}$ International Law Commission, Second Report on Crimes Against Humanity, UN Doc. A/CN.4/690 (Jan. 21, 2016) (prepared by Special Rapporteur Sean Murphy) [hereinafter Second Report on Crimes Against Humanity].

722016 Report, supra note 1 , at 242, paras. 82, 83; see also id. at 246-80, para. 85.

${ }^{73} \mathrm{Id}$. at 247 (draft Article 5(1)-(2)).

${ }^{74}$ Id. (draft Article 5(3)).

${ }^{75}$ Rome Statute of the International Criminal Court, Art. 28, July 17, 1998, 2187 UNTS 90.

${ }^{76} 2016$ Report, supra note 1, at 247-48 (draft Article 5(4)-(6)).
} 
to establish the liability of legal persons for the offences referred to in this draft article[; . . . such liability of legal persons may be criminal, civil or administrative.",77

Following the same approach as many treaties addressing crimes, draft Article 6 provides that each state must establish, in certain cases, jurisdiction over the offenses referred to in draft Article 5. ${ }^{78}$ Those cases include situations when the crime occurs in territory under that state's jurisdiction, when it has been committed by one of its nationals, or when the offender is present in territory under the state's jurisdiction.

Draft Article 7 focuses on steps to be taken by a state when such crimes may have occurred in its territory. It reads: "Each State shall ensure that its competent authorities proceed to a prompt and impartial investigation whenever there is reasonable ground to believe that acts constituting crimes against humanity have been or are being committed in any territory under its jurisdiction. ${ }^{, 79}$ As the commentary to this draft article explains, ${ }^{80}$ a comparable obligation features in some treaties addressing crimes, such as in Article 12 of the Convention Against Torture. $^{81}$

Draft Article 8 provides for certain preliminary measures to be taken by the state in the territory under whose jurisdiction an alleged offender is present. ${ }^{82}$ First, it calls upon the state to "take the person into custody or take other legal measures to ensure his or her presence," in accordance with that state's law, but "only for such time as is necessary to enable any criminal, extradition, or surrender proceedings to be instituted." $" 83$ Second, it requires the state immediately to "make a preliminary inquiry into the facts." 84 Third, it provides that the state shall also immediately notify the states able to exercise jurisdiction pursuant to draft Article 6 of the measures that it has taken and indicate whether the state itself intends to exercise jurisdiction. Doing so allows those other states to consider whether they wish to exercise jurisdiction, in which case they might seek extradition of the alleged offender. ${ }^{85}$

Draft Article 9, entitled “Aut dedere aut judicare," provides:

\footnotetext{
${ }^{77}$ Id. at 248 (draft Article 5(7)). This provision is modeled on Article 3(4) of the Optional Protocol to the Convention on the Rights of the Child on the Sale of Children, Child Prostitution and Child Pornography, May 25, 2000, 2171 UNTS 227.

${ }^{78} 2016$ Report, supra note 1, at 265-66 (draft Article 6).

${ }^{79}$ Id. at 269 (draft Article 7).

${ }^{80} I d$. at $269-71$.

${ }^{81}$ Convention Against Torture and Other Cruel, Inhuman or Degrading Treatment or Punishment, Art. 12, Dec. 10, 1984, S. TREATY DOC. No. 100-20 (1988), 1465 UNTS 85 (“Each State Party shall ensure that its competent authorities proceed to a prompt and impartial investigation, wherever there is reasonable ground to believe that an act of torture has been committed in any territory under its jurisdiction.").

${ }^{82} 2016$ Report, supra note 1, at 271 (draft Article 8).

${ }_{83}^{83} \mathrm{Id}$.

${ }^{84} \mathrm{Id}$.

${ }^{85} \mathrm{Id}$. at $271-72$.
} 
The State in the territory under whose jurisdiction the alleged offender is present shall submit the case to its competent authorities for the purpose of prosecution, unless it extradites or surrenders the person to another State or competent international criminal tribunal. Those authorities shall take their decision in the same manner as in the case of any other offence of a grave nature under the law of that State. ${ }^{86}$

This language envisages the possibility of a state satisfying its aut dedere aut judicare obligation by surrendering the alleged offender to an international criminal tribunal, such as the International Criminal Court. In some instances, the state may be obligated to so surrender the alleged offender, depending on the state's legal relationship with the international criminal tribunal; to the extent that the state has no legal obligation with respect to such a tribunal, the state remains obligated to submit the case to its competent authorities, unless it extradites the person to another state. ${ }^{87}$

Draft Article 10 addresses the rights of the alleged offender. ${ }^{88}$ Paragraph 1 asserts that such persons "shall be guaranteed at all stages of the proceedings fair treatment, including a fair trial, and full protection of his or her rights under applicable national and international law, including human rights law." Paragraph 2 provides that when the person is in prison, custody, or detention by a state that is not of his or her nationality, the person is entitled to communicate without delay with a representative of his or her state, to be visited by such a representative, and to be informed without delay of his or her rights in this regard.

In his second report, the special rapporteur indicated that a third report on this topic could address issues such as (1) rights and obligations applicable to the extradition of the alleged offender; (2) rights and obligations applicable to mutual legal assistance in connection with criminal proceedings; (3) the obligation of nonrefoulement in certain circumstances; (4) dispute settlement and monitoring mechanisms; and (5) conflict avoidance with treaties such as the Rome Statute of the International Criminal Court. ${ }^{89}$

\section{Protection of the Atmosphere}

The Commission considered the third report on the protection of the atmosphere by the special rapporteur, Shinya Murase (Japan). ${ }^{90}$ Based on that report, the Commission adopted a

\footnotetext{
${ }^{86}$ Id. at 273 (draft Article 9).

${ }^{87}$ Id. at $273-76$.

${ }^{88}$ Id. at 276-77 (draft Article 10).

${ }^{89}$ Second Report on Crimes Against Humanity, supra note 71, at 100, para. 202.

${ }^{90}$ See International Law Commission, Third Report on the Protection of the Atmosphere, UN Doc. A/CN.4/692 (Feb. 25, 2016) (prepared by Special Rapporteur Shinya Murase). For discussion of prior work on this topic, see Murphy, Sixty-Fifth Session, supra note 2, at 56-57; Murphy, Sixty-Sixth Session, supra note 2, at 139; Murphy, Sixty-Seventh Session, supra note 2, at 832-35.
} 
preambular paragraph as well as five new draft guidelines_-draft Guidelines 3, 4, 5, 6, and 7with commentary. ${ }^{91}$

Draft Guideline 3 asserts that "States have the obligation to protect the atmosphere by exercising due diligence in taking appropriate measures, in accordance with applicable rules of international law, to prevent, reduce or control atmospheric pollution and atmospheric degradation." 92 According to the commentary, this draft guideline is "central to the present draft guidelines" and from it flow draft Guidelines 4, 5, and 6. ${ }^{93}$ Draft Guideline 4 indicates that "States have the obligation to ensure that an environmental impact assessment is undertaken of proposed activities under their jurisdiction or control which are likely to cause significant adverse impact on the atmosphere in terms of atmospheric pollution or atmospheric degradation." 94 Draft Guideline 5 provides that "utilization [of the atmosphere] should be undertaken in a sustainable manner," noting that "[s]ustainable utilization of the atmosphere includes the need to reconcile economic development with protection of the atmosphere."95 Draft Guideline 6 maintains that the "atmosphere should be utilized in an equitable and reasonable manner, taking into account the interests of present and future generations." 96

Draft Guideline 7 relates: "Activities aimed at intentional large-scale modification of the atmosphere should be conducted with prudence and caution, subject to any applicable rules of international law." 97 By its terms, this guideline addresses both activities designed to use the atmosphere for beneficial purposes, such as weather modification to improve crops, and activities designed to improve the atmosphere itself, such as through removing carbon from the atmosphere and sequestering it in the soil or marine environment. ${ }^{98}$ The latter type of activity, sometimes referred to as "geo-engineering," involves new techniques that many regard as potentially harmful to the environment of the lithosphere. ${ }^{99}$ Given that the draft guidelines might be viewed as authorizing such activities, the commentary to this draft guideline notes:

912016 Report, supra note 1, at 282, para. 93.

${ }^{92}$ Id. at 286 (draft Guideline 3).

${ }^{93}$ Id.

${ }^{94}$ Id. at 288-89 (draft Guideline 4).

${ }^{95}$ Id. at 291 (draft Guideline 5).

${ }^{96}$ Id. at 292 (draft Guideline 6).

${ }^{97}$ Id. at 293 (draft Guideline 7).

${ }^{98} \mathrm{Id}$. at 294.

${ }^{99}$ Id. For example, in 2010, states parties to the Convention on Biological Diversity, meeting in Nagoya, Japan, decided that

no climate-related geo-engineering activities that may affect biodiversity take place, until there is an adequate scientific basis on which to justify such activities and appropriate consideration of the associated risks for the environment and biodiversity and associated social, economic and cultural impacts, with the exception of small scale scientific research studies that would be conducted in a controlled setting in accordance with Article 3 of the Convention, and only if they are justified by the need to gather specific scientific data and are subject to a thorough prior assessment of the potential impacts on the environment. 
(12) A number of members remained unpersuaded that there was a need for a draft guideline on this matter, which essentially remains controversial, and the discussion on it was evolving, and is based on scant practice. Other members were of the view that the draft guideline could be enhanced during second reading. ${ }^{100}$

\section{Jus Cogens}

During the sixty-seventh session, the Commission moved the topic of jus cogens onto the current program of work and appointed Dire D. Tladi (South Africa) as special rapporteur. ${ }^{101}$ In a first report submitted for the sixty-eighth session, ${ }^{102}$ the special rapporteur proposed three draft conclusions, two of which were referred to the drafting committee. ${ }^{103}$

As provisionally adopted within the drafting committee, draft Conclusion 1 states: "The present draft conclusions concern the identification and legal effects of peremptory norms of general international law (jus cogens)."104 The special rapporteur also proposed two paragraphs for the other draft conclusion (originally designated as draft Conclusion 3) that were sent to the drafting committee. So far, the drafting committee has provisionally adopted just the first paragraph of that draft conclusion (now designated as draft Conclusion 2), which provides:

A peremptory norm of general international law (jus cogens) is a norm accepted and recognized by the international community of States as a whole as a norm from which no derogation is permitted and which can be modified only by a subsequent norm of general international law having the same character. ${ }^{105}$

This language tracks the language of the second sentence of VCLT Article 53. ${ }^{106}$ The second paragraph of this draft conclusion proposed by the special rapporteur, which has not yet been adopted by the drafting committee, reads: "Norms of jus cogens protect the fundamental values of the international community, are hierarchically superior to other norms of international law

Convention on Biological Diversity, Tenth Meeting of the Conference of the Parties, Decision X/33, Biodiversity and Climate Change, Doc. No. UNEP/CBD/COP/DEC/X/33, para. 8(w) (2010) (citation omitted), available at www.cbd.int/decisions/cop/?m=cop-10.

${ }^{100} 2016$ Report, supra note 1, at 296.

${ }^{101}$ Report of the International Law Commission on the Work of Its Sixty-Seventh Session, UN GAOR, 70th Sess., Supp. No. 10, at 138, para. 286, UN Doc. A/70/10 (Aug. 14, 2015).

${ }_{102}$ See International Law Commission, First Report on Jus Cogens, UN Doc. A/CN.4/693 (Mar. 8, 2016) (prepared by Special Rapporteur Dire Tladi) [hereinafter First Report on Jus Cogens].

${ }^{103} 2016$ Report, supra note 1, at 297, para. 100.

${ }^{104}$ International Law Commission, Statement of the Chairman of the Drafting Committee, Mr. Pavel Šturma, "Jus Cogens," annex (Aug. 9, 2016), available at

http://legal.un.org/docs/?path=../ilc/documentation/english/statements/2016_dc_chairman_statement_jc.pdf\&lang=E [hereinafter Statement of the Chairman of the Drafting Committee on Jus Cogens].

${ }^{105} I d$.

${ }^{106}$ VCLT, supra note 60, Art. 53. 
and are universally applicable." ${ }^{\prime 107}$ That language, which does not appear in the VCLT, elicited conflicting views within the Commission and the drafting committee. ${ }^{108}$ According to the report of its chair, the drafting committee next year will consider "moving paragraph 2, or a further version thereof, into a separate draft conclusion or conclusions." 109

The special rapporteur has indicated that a second report in 2017 could be dedicated to the rules for identifying of norms of jus cogens, including the question of the sources of jus cogens, "that is, whether jus cogens emanate from treaty law, customary international law, general principles of law or other sources." ${ }^{110}$ Further, the second report "will also consider the relationship between jus cogens and non-derogation clauses in human rights treaties."111 A third report in 2018 might consider the consequences of jus cogens, while a fourth report in 2019 could address miscellaneous issues. ${ }^{112}$

\section{Protection of the Environment in Relation to Armed Conflicts}

The Commission considered the third report on the protection of the environment in relation to armed conflicts by the special rapporteur, Marie G. Jacobsson (Sweden). ${ }^{113}$ While her first report focused on rules of international law that operate in relation to the environment even in the absence of armed conflict and her second report focused on rules of international law that apply once armed conflict breaks out, the third report addressed a mixture of rules, including those applicable after the armed conflict ends.

The draft principles on this topic adopted to date are at differing levels of completion, and the Commission will need to decide in 2017 how best to proceed given that the special rapporteur is not seeking reelection to the Commission. Possibilities include appointing a new special rapporteur or establishing a working group, as was done in 2012 on the topic of aut dedere aut judicare. ${ }^{114}$

To date, the Commission has adopted introductory commentary and eight draft principles with commentary on the following issues: scope (draft Principle 1); purpose (draft Principle 2); designation of protected zones (draft Principle 5); general protection of the natural environment

\footnotetext{
1072016 Report, supra note 1, at 299, para. 110 n.1296.

${ }^{108}$ Id. at 303, paras. 125-27.

${ }^{109}$ Statement of the Chairman of the Drafting Committee on Jus Cogens, supra note 104, at 5.

${ }^{110}$ First Report on Jus Cogens, supra note 102, at 46, para. 75.

${ }^{111} \mathrm{Id}$.

${ }^{112} I d$. at 46, para. 76.

${ }^{113}$ International Law Commission, Third Report on the Protection of the Environment in Relation to Armed Conflicts, UN Doc. A/CN.4/700 (June 3, 2016) (prepared by Special Rapporteur Marie Jacobsson) [hereinafter Third Report on the Protection of the Environment in Relation to Armed Conflicts]. For discussion of prior work on this topic, see Murphy, Sixty-Fifth Session, supra note 2, at 55-56; Murphy, Sixty-Sixth Session, supra note 2, at 143; Murphy, Sixty-Seventh Session, supra note 2, at 838-41.

${ }^{114}$ See Murphy, Sixty-Fourth Session, supra note 2, at 174-75.
} 
during armed conflict (draft Principle 9); application of the law of armed conflict to the natural environment (draft Principle 10); environmental considerations when applying the principle of proportionality and the rules on military necessity (draft Principle 11); prohibition on reprisals (draft Principle 12); and protected zones (draft Principle 13). ${ }^{115}$

Further, the drafting committee has provisionally adopted nine additional draft principles on measures to enhance the protection of the environment (draft Principle 4); protection of the environment of indigenous peoples (draft Principle 6); agreements concerning the presence of military forces in relation to armed conflict (draft Principle 7); peace operations (draft Principle 8); peace processes (draft Principle 14); post-armed conflict environmental assessments and remedial measures (draft Principle 15); remnants of war (draft Principle 16); remnants of war at sea (draft Principle 17); and sharing and granting access to information (draft Principle 18). These draft principles and their commentary have not yet been adopted by the Commission. ${ }^{116}$

\section{Immunity of State Officials from Foreign Criminal Jurisdiction}

The Commission had before it, towards the end of the sixty-eighth session, the fifth report on "immunity of State officials from foreign criminal jurisdiction" by its second special rapporteur for this topic, Concepción Escobar Hernández (Spain). ${ }^{117}$ This report addresses the possibility of "limitations and exceptions" to such immunity ${ }^{118}$ and proposes a single draft article:

Draft article 7

Crimes in respect of which immunity does not apply

1. Immunity shall not apply in relation to the following crimes:

(a) Genocide, crimes against humanity, war crimes, torture and enforced disappearances;

(b) Crimes of corruption;

${ }^{115} 2016$ Report, supra note 1, at 308, para. 145; id. at 321-40, para. 189.

${ }_{116}^{116}$ Id. at 308 , para. $146 \&$ n. 1309 .

${ }^{117}$ International Law Commission, Fifth Report on Immunity of State Officials from Foreign Criminal Jurisdiction, UN Doc. A/CN.4/701 (June 14, 2016) (prepared by Special Rapporteur Concepción Escobar Hernández)

[hereinafter Fifth Report on Immunity of State Officials]. For discussion of prior work on this topic, see Murphy, Sixty-Fourth Session, supra note 2, at 169-71; Murphy, Sixty-Fifth Session, supra note 2, at 41-48; Murphy, SixtySixth Session, supra note 2, at 139-40; Murphy, Sixty-Seventh Session, supra note 2, at 842.

${ }_{118} 2016$ Report, supra note 1, at 342, para. 193. 
(c) Crimes that cause harm to persons, including death and serious injury, or to property, when such crimes are committed in the territory of the forum State and the State official is present in said territory at the time that such crimes are committed.

2. Paragraph 1 shall not apply to persons who enjoy immunity ratione personae during their term of office.

3. Paragraphs 1 and 2 are without prejudice to:

(a) Any provision of a treaty that is binding on the forum State and the State of the official, under which immunity would not be applicable;

(b) The obligation to cooperate with an international tribunal which, in each case, requires compliance by the forum State. ${ }^{119}$

At the point when the Commission was scheduled to debate the fifth report, including this draft article, the report was available to the Commission only in two of the six official languages of the United Nations (Spanish and English). ${ }^{120}$ Nevertheless, and on an exceptional basis, the debate was commenced with an introduction of the report by the special rapporteur ${ }^{121}$ in which she explained that

although the practice was varied, it revealed a clear trend towards considering the commission of international crimes as a bar to the application of the immunity ratione materiae of State officials from foreign criminal jurisdiction. This was on the basis that: (a) such crimes were not considered official acts, or were an exception to immunity, owing to the serious nature of the crime; or (b) they undermined the values and principles recognized by the international community as a whole. ${ }^{122}$

The special rapporteur's introduction was followed by interventions of those members who wished to speak during the sixty-eighth session, but the debate was not completed and will continue in the sixty-ninth session, at which time the report will be available in the six official languages of the United Nations. ${ }^{123}$

\footnotetext{
${ }^{119}$ Id., para. 196 n.1408.

${ }^{120}$ Id., para. 193.

${ }^{121} \mathrm{Id}$. at 342-45, paras. 196-208.

${ }^{122} I d$. at 344, para. 204.

${ }^{123} I d$. at 342, para. 193.
} 
The initial debate at the sixty-eighth session suggests that a divide may exist among the members of the Commission as to whether the draft article reflects lex lata or even lex ferenda. $^{124}$ In the debate,

[s]ome members were critical of the report for not faithfully following the analytical process of identification of customary international law referred to therein. Moreover, the conclusions that were sometimes reached were often irreconcilable with certain other assertions made in the report. In particular, concerns were expressed regarding the treatment of the case law, which was of varied origin, the choice of which appeared selective, the reliance in some cases on separate and dissenting opinions, as well as reliance on [a] limited sample of national legislation, some of which it was suggested was of limited relevance in the consideration of the topic. It was further noted that a trend towards an exception in domestic courts, even if it existed, was not a general practice for purposes of constituting a rule of customary international law. ${ }^{125}$

Part of the difficulty in reaching consensus also may derive from the methodology employed when analyzing state practice in this area. In that regard, several issues arise with respect to the methodology used in the fifth report, many of which were touched upon in the initial part of the Commission's debate. First, the report in several places refers to a "clear and growing trend" towards exceptions to immunity, ${ }^{126}$ but it neither provides any empirical assessment as to the existence of a "trend" nor indicates a time period (such as over the past ten years) for such a trend. Indeed, the evidence marshaled in the report does not signal any particular arc in the development of exceptions or limitations; support for the draft article is derived indiscriminately from different time periods: the 1950 Nuremberg Principles; ${ }^{127}$ the Eichmann trial in the $1960 \mathrm{~s} ;{ }^{128}$ the 1976 U.S. Foreign Sovereign Immunities Act; ${ }^{129}$ the Barbie trial in the $1980 \mathrm{~s} ;{ }^{130}$ the establishment of the ad hoc tribunals in the $1990 \mathrm{~s} ;{ }^{131}$ and the adoption of

${ }^{124}$ See id. at 345-51, paras. 209-46.

${ }^{125} I d$. at 346, para. 214.

${ }^{126}$ See, e.g., Fifth Report on Immunity of State Officials, supra note 117, at 11, para. 19(i) ("clear and growing trend"); see also id. at 53, para. 121 (noting that "the majority trend is to accept the existence of certain limitations and exceptions to such immunity"); $i d$. at 73, para. 179 ("clear trend"); id. at 76, para. 184(a) ("trend in favour"); id. at 78, para. 188 ("clear trend"); see also 2016 Report, supra note 1, at 344, para. 204 ("a clear trend towards considering the commission of international crimes as a bar to the application of the immunity ratione materiae of State officials from foreign criminal jurisdiction"); id., para. 205 ("[A]lthough there might be doubt as to the existence of a relevant general practice amounting to a custom, there was a clear trend that reflected an emerging custom.")).

${ }^{127}$ Id. at 56, para. 127 (citing Nuremberg Principles, [1950] 2 Y.B. INT’L L. COMM’N 374, UN Doc. A/CN.4/SER.A/1950/Add.I (pt. 2)).

${ }^{128}$ Id. at 50 n.233 (citing Att'y Gen. of Israel v. Eichmann, 36 ILR 5 (Dist. Ct. Jerusalem 1961), aff'd, 36 ILR 277 (Isr. Sup. Ct. 1962)).

${ }^{129}$ Id. at 25, para. 44 (citing Foreign Sovereign Immunities Act of 1976, Pub. L. No. 94-583, 90 Stat. 2891 (codified in scattered sections of 28 U.S.C.)).

${ }^{130}$ Id. at 50, para. 114 n.233 (citing Fédération Nationale des Déportées v. Barbie, Cour de cassation [supreme court for judicial matters], Oct, 6, 1983, 78 ILR 124 (Fr.)).

${ }^{131} I d$. at 68 , para. 163. 
recent national legislation on international crimes. ${ }^{132}$ These various fragments of information do not appear to establish either a "clear" or "growing" trend in the law. Moreover, some evidence seems to suggest either the lack of a trend, for example in recent cases at the International Court of Justice ${ }^{133}$ and before the European Court of Human Rights, ${ }^{134}$ or perhaps a countertrend in the sense of narrowing the scope of national laws. ${ }^{135}$ Arguably, the repeated emphasis on a "trend" in the fifth report is an implicit acknowledgment by the special rapporteur that settled law on this issue may not support the proposed limitations and exceptions and therefore that whatever the Commission says on this matter would fall within the realm of progressive development of the law.

Second, the report seems to downplay the lack of consensus among states as to the existence of limitations and exceptions as a matter of either lex lata or lex ferenda. The report acknowledges at paragraph 20(a) that "there is no clear consensus among States as to which questions concerning exceptions would be included in each of the two categories [lex lata or lex ferenda]." $" 136$ Yet the report then does not take account of that significant observation when considering whether state practice and opinio juris support the existence, under present law, of a rule on exceptions to immunity. ${ }^{137}$

Third, the report discusses ${ }^{138}$ but ultimately abandons any effort to distinguish among certain very different situations:

\footnotetext{
${ }^{132}$ Id. at 24, paras. 55-59 (citing to the Netherlands' 2003 International Crimes Act, a 2003 amendment to Niger's Penal Code, and various laws adopted by states when joining the Rome Statute); see also id. at 74, para. 181 (listing overall factors).

${ }^{133}$ See Arrest Warrant of 11 April 2000 (Dem. Rep. Congo v. Belg.), 2002 ICJ REP. 3 (Feb. 14) [hereinafter Arrest Warrant]; Certain Questions of Mutual Assistance in Criminal Matters (Djib. v. Fr.), 2008 ICJ REP. 177 (June 4); Jurisdictional Immunities of the State (Ger. v. It.; Greece intervening), 2012 ICJ REP. 99 (Feb. 3) [hereinafter Jurisdictional Immunities].

${ }^{134}$ Al-Adsani v. United Kingdom, 2001-XI Eur. Ct. H.R. 761 (Grand Chamber); McElhinney v. Ireland, 2001-XI Eur. Ct. H.R. 763 (Grand Chamber); Kalogeropoulou v. Greece, 2002-X Eur. Ct. H.R. 415; Jones v. United Kingdom, App. No. 34356/06 (Eur. Ct. H.R. Jan. 14, 2014).

${ }^{135}$ For example, the fifth report places some reliance on Belgium's national law regulating international crimes. See Fifth Report on Immunity of State Officials, supra note 117, at 29, para. 54. To the extent that such a law is relevant, the law was scaled back considerably from its origins so that "Belgian courts ... only have jurisdiction over international crimes if the accused is Belgian or has his primary residence in Belgium; if the victim is Belgian or has lived in Belgium for at least three years at the time the crimes were committed; or if Belgium is required by treaty to exercise jurisdiction over the case.” Human Rights Watch, Belgium: Universal Jurisdiction Law Repealed (Aug. 1, 2003), at https://www.hrw.org/news/2003/08/01/belgium-universal-jurisdiction-law-repealed. Thus, the revised law "considerably reduce[d] the victims' ability to obtain direct access to the courts—unless the accused is Belgian or has his primary residence in Belgium, the decision whether to proceed with any complaint rests entirely with the state prosecutor." Id. Such developments do not sit easily with the idea of a "trend" in one direction.

${ }^{136}$ Fifth Report on Immunity of State Officials, supra note 117, at 13, para. 20(a).

${ }^{137} I d$. at $74-78$, paras. $181-89$.

${ }^{138} I d$. at $71-73$, paras. $170-76$.
} 
- situations where there is what the special rapporteur calls a "limitation" on immunity (that is, the act at issue is not an "official" act and therefore the question of immunity ratione materiae simply does not arise);

- situations where there is an "exception" to immunity (for example, the act at issue is official, but is so heinous that immunity is denied); and

- situations where immunity is being denied based on some other theory (for example, to help ensure compensation for victims).

Instead, all these situations are grouped together, making it difficult to know the ground on which the components of draft Article 7 are based. For example, the best justification for the absence of immunity for the crime of corruption may be that a corrupt act, by its nature, is for private gain and hence not an official act, and therefore the issue of immunity does not arise. If so, grouping a corrupt act with other kinds of acts may create confusion, rather than clarity.

Fourth, the report finds great relevance in precedents arising in the area of immunity of states from civil jurisdiction whenever they support the proposed draft Article $7^{139}$ but seems to downplay such precedents when they are not helpful. ${ }^{140}$ For example, the report cites to certain civil cases under national law that purportedly establish exceptions to immunity so as to support a proposition that such exceptions also exist with respect to that state's criminal law. ${ }^{141}$ But when it comes to considering international case law, such as cases before the European Court of Human Rights, where exceptions to immunity are rejected in the context of civil cases, those precedents are deemed by the report to be of no great significance because they concern civil and not criminal matters. ${ }^{142}$

Fifth, and likewise, the report leans on treaty practice when it supports proposed draft Article 7 but sets it aside when such treaty practice is not supportive. ${ }^{143}$ For example, the report concludes that the "territorial tort" exception that exists in treaties addressing immunity of states from civil jurisdiction supports an analogous exception in the context of criminal jurisdiction; such treaties include the 2004 UN Convention on Jurisdictional Immunities of States and Their Property ${ }^{144}$ and the 1972 European Convention on State Immunity. ${ }^{145}$ Yet if those treaties are

\footnotetext{
${ }^{139} I d$. at 83-86, paras. 206-14 (e.g., access of victims to remedies).

${ }^{140}$ Ultimately, the report concludes that exceptions to one regime cannot be transposed onto the other. Id. at 66, para. 155. But see HAZEL FoX \& PHILIPPA WeBb, THE LAW OF STATE IMMUNITY 85 (3d ed. 2013) ("Civil jurisdiction can thus in the last resort, and even with the special rules relating to satisfaction of judgments against State property introduced by the restrictive doctrine of immunity, be regarded as based on criminal jurisdiction.").

${ }^{141}$ Fifth Report on Immunity of State Officials, supra note 117, at 51-53, paras. 116-20.

${ }^{142} I d$. at 39-42, paras. 87-95.

${ }^{143} \mathrm{Id}$. at 17-24, paras. 23-41.

${ }^{144} I d$. at 18-19, paras. 26-27 (citing in part United Nations Convention on Jurisdictional Immunities of States and Their Property, GA Res. 59/38, annex (Dec. 2, 2004)).
} 
relevant in support of an analogous exception to immunity from criminal jurisdiction, then they presumably should be equally relevant with respect to the absence of any exception in those treaties relating to genocide, crimes against humanity, war crimes, torture, enforced disappearance, or corruption. In other words, if states in those treaties (and in their national laws on immunity of states) did not include exceptions to state immunity for an allegation of genocide, crimes against humanity, war crimes, and so on, then that, too, would appear directly pertinent to whether any such exception exists with respect to criminal jurisdiction. Indeed, given that the UN Convention on Jurisdictional Immunities of States and Their Property was adopted in 2004 without any such exceptions of this kind, this fact does not fit within the asserted narrative of a "trend" towards limitations and exceptions.

Perhaps more importantly, widely adhered-to treaties expressly addressing immunity for certain categories of state officials in the context of allegations of criminal conduct also contain no such exceptions. As the report acknowledges, treaties directly governing immunity of state officials, such as diplomats and consular officials, "do not contain provisions contemplating any form of exception or limitation to immunity as regards criminal jurisdiction." 146 Thus, in the Vienna Conventions relating to diplomats and consular officials, ${ }^{147}$ which have been adhered to by 190 and 179 states respectively, there is no exception to immunity relating to genocide, crimes against humanity, war crimes, and so on. Yet the report does not consider the significance of the lack of such exceptions in treaties that states, by all accounts, continue to regard as entirely acceptable. Rather, the report downgrades these treaties as "mainly describ[ing] a model of immunity ratione personae" though, as the report itself ultimately concedes, they also concern immunity ratione materiae. ${ }^{148}$ Indeed, for acts performed by such a person in the exercise of his or her diplomatic or consular functions, immunity continues to subsist even after those functions have come to an end.

Likewise, treaties that specifically address the crime of genocide, war crimes, enforced disappearance, and apartheid do not, at least expressly, deny immunity to state officials. The report asserts that Article IV of the Genocide Convention "indirectly postulates the irrelevance of

\footnotetext{
${ }^{145}$ Id. at 19, para. 28 (citing in part European Convention on State Immunity, May 16, 1972, ETS No. 74, 1495 UNTS 182).

${ }^{146}$ Fifth Report on Immunity of State Officials, supra note 117, at 17-18, para. 24. The Commission's topic does not address immunities that exist under "special rules of international law," such as those on the immunity of diplomats and consular officials. As noted in the fifth report, draft Article 1, paragraph 2, provides: "The present draft articles are without prejudice to the immunity from criminal jurisdiction enjoyed under special rules of international law, in particular by persons connected with diplomatic missions, consular posts, special missions, international organizations and military forces of a State." Id. at 96 (Annex I).

${ }^{147}$ Id. at 17, para. 24 (citing Vienna Convention on Diplomatic Relations, Art. 31(1), Apr. 18, 1961, 500 UNTS 95, and Vienna Convention on Consular Relations, Arts. 43, 53, Apr. 24, 1963, 596 UNTS 261).

${ }^{148} I d$. at 18 , paras. $24-25$.
} 
official status," ${ }^{149}$ but many view that language as speaking only to the criminal responsibility of the individual and not to his or her immunity from foreign criminal jurisdiction. ${ }^{150}$ In any event, the report could have noted that Article VI of the Genocide Convention limits the obligation to prosecute alleged offenders to the state in whose territory the genocide allegedly occurred or by an international criminal tribunal, which means that if immunity is impliedly being denied, it is only in that narrower context. Likewise, conventions on corruption contain no provisions expressly denying immunity to foreign government officials, though they do contain provisions relating to the immunity of government officials within their own state. ${ }^{151}$ If there was, in fact, a "trend" to deny immunity to state officials in foreign jurisdictions for enforced disappearance, for example, it might have been expected that the drafters of the relatively recent International Convention for the Protection of All Persons from Enforced Disappearance ${ }^{152}$ _adopted in 2006 - would have included a provision to that effect. Yet they did not do so. ${ }^{153}$

Implicit waiver of the immunity of a state official in such treaties is far from certain, ${ }^{154}$ but perhaps it can be found when the crime is so defined that it may only be committed by state officials - such as in the Convention Against Torture - and every state party has an obligation to

\footnotetext{
${ }^{149}$ Id. at 21, para. 33 (citing Convention on the Prevention and Punishment of the Crime of Genocide, Art. 4, Dec. 9 , 1948, 78 UNTS 277 ("Persons committing genocide or any of the other acts enumerated in article III shall be punished, whether they are constitutionally responsible rulers, public officials or private individuals.")).

${ }^{150}$ The same is true of the report's discussion of the Commission's 1996 Draft Code of Crimes, which indicated the irrelevance of official position with respect to "criminal responsibility" and mitigation of "punishment," not withholding of immunity. See id. at 56, para. 128 n.262 (quoting Draft Code of Crimes Against the Peace and Security of Mankind, Art. 7, in Report of the International Law Commission on the Work of Its Forty-Eighth Session, [1996] 2 Y.B. INT'L L. CoMm'N 17, UN GAOR, 51st Sess., Supp. No. 10, UN Doc. A/51/10 (1996)). The Commission's commentary simply referred to punishment in "appropriate proceedings," $i d$. at 57-58, para. 130, and did not indicate whether national courts should include foreign courts.

${ }^{151} I d$. at 23-24, paras. 37-41. For example, the United Nations Convention Against Corruption provides in part:
}

Each State Party shall take such measures as may be necessary to establish or maintain ... an appropriate balance between any immunities or jurisdictional privileges accorded to its public officials for the performance of their functions and the possibility, when necessary, of effectively investigating, prosecuting and adjudicating offences established in accordance with this Convention.

UN Convention Against Corruption, Art. 30(2), Oct. 31, 2003, 2349 UNTS 41 (emphasis added).

${ }^{152}$ International Convention for the Protection of All Persons from Enforced Disappearance, Dec. 20, 2006, 2716 UNTS 3 [hereinafter Enforced Disappearance Convention].

${ }^{153}$ An initial draft of the Enforced Disappearance Convention contained an article explicitly excluding immunity of state officials other than diplomats. See Draft International Convention for the Protection of All Persons from Enforced Disappearance, UN Doc. E/CN.4/Sub.2/1998/19, annex, Art. 10(2) (Aug. 19, 1998) ("No privileges, immunities or special exemptions shall be granted in such trials, subject to the provisions of the Vienna Convention on Diplomatic Relations."). States decided to drop that article in the final version of the Convention. The Convention does address immunities but only in the context of granting them to the members of that treaty's committee of experts. See Enforced Disappearance Convention, supra note 153, Art. 26(8).

${ }^{154}$ See Arrest Warrant, supra note 133, para. 59 ("[A]lthough various international conventions on the prevention and punishment of certain serious crimes impose on States obligations of prosecution or extradition, thereby requiring them to extend their criminal jurisdiction, such extension of jurisdiction in no way affects immunities under customary international law ....”). 
exercise jurisdiction over any alleged offender who turns up in its territory. ${ }^{155}$ In such circumstances, the idea of an implied waiver may be at its strongest. Even so, it would be purely a treaty-based exception to immunity, essentially predicated on a waiver when the official's state joins the treaty, and would only operate when the offender is present in the forum state. Further, the International Court of Justice's admonition in the ELSI case may be pertinent; the Court stated that it was "unable to accept that an important principle of customary international law should be held to have been tacitly dispensed with, in absence of any words [in the treaty] making clear an intention to do so." ${ }^{, 156}$ Further, if such widely adhered-to treaties in some fashion support the exceptions indicated in draft Article 7, why are other exceptions also not suggested by similar treaties that have attracted widespread adherence, such as treaties on sexual slavery, child prostitution or pornography, trafficking in narcotics, attacks on diplomats, taking of hostages, terrorist bombings, or cybercrime?

Sixth, some concern relates to the use of national legislation to support the proposed exceptions in draft Article 7. ${ }^{157}$ As the report notes, "[N]ational laws regulating jurisdictional immunity are very few in number," 158 which presents a problem for identifying settled law relating to any exceptions. Further, most of these national laws relate to immunity of states, not immunity of officials from criminal jurisdiction. Even so, as was the case with treaties on state immunity, the report indicates that these national laws on state immunity provide for a "territorial tort" exception, which purportedly in turn supports an analogous exception to immunity in the context of criminal jurisdiction.. Yet, as was the case with treaties, it should be acknowledged that these national laws on state immunity contain no exceptions for genocide, crimes against humanity, war crimes, and so on. As previously noted, if these laws on state immunity are relevant to the exceptions for immunity from criminal jurisdiction, then they would also appear relevant to the exceptions that they do not contain.

Likewise, while the report appropriates the "territorial tort" exception in these national laws on state immunity in support of an analogous exception to immunity from criminal jurisdiction, the report does not address an important aspect of why the former exception developed. The origins of the "territorial tort" exception to immunity from civil jurisdiction, to a large extent, lie in the idea that it is reasonable for a foreign state to be civilly liable for insurable risks. For example, if a state plans to equip its foreign embassy with a fleet of vehicles and drivers, then it should take out an automobile insurance policy, so as to address any injuries caused in the host state from the negligence of its drivers. But that explanation for the "territorial

\footnotetext{
${ }^{155}$ Fifth Report on Immunity of State Officials, supra note 117, at 21, para. 33.

${ }^{156}$ Elettronica Sicula S.p.A. (ELSI) (U.S. v. It.), 1989 ICJ REP. 15, para. 50 (July 20).

${ }^{157}$ Fifth Report on Immunity of State Officials, supra note 117, at 24-31, paras. 42-59; see also International Law Commission, Second Report on Immunity of State Officials from Foreign Criminal Jurisdiction, paras. 81-86, 94(p), UN Doc. A/CN.4/631* (June 10, 2010) (prepared by Special Rapporteur Roman Kolodkin); International Law Commission, Memorandum by the Secretariat on Immunity of State Officials from Foreign Criminal Jurisdiction, paras. 162-65, UN Doc. A/CN.4/596 (Mar. 31, 2008).

${ }^{158}$ Fifth Report on Immunity of State Officials, supra note 117, at 25, para. 44.
} 
tort" exception does not easily translate into an exception to immunity for criminal behavior of officials. ${ }^{159}$

Moreover, while the report seizes upon the "territorial tort" exception in national laws on state immunity, it does not squarely confront that these national laws typically maintain immunity of the state for public acts (jure imperii). ${ }^{160}$ The report acknowledges that these laws have exceptions for state acts that are essentially commercial or private (jure gestionis) ${ }^{161}$ but does not acknowledge the other side of the coin, which is the preservation of immunity for acts jure imperii. If the existence of a "territorial tort" exception in such laws is relevant to immunity of state officials from foreign criminal jurisdiction, then the retention of immunity for public acts, such as military activities in armed conflict, ${ }^{162}$ would seem equally relevant, a point that was addressed in the Jurisdictional Immunities of the State case. ${ }^{163}$

The report also notes several recent national laws implementing the Rome Statute that are important when considering whether State practice supports the exceptions to immunity found in draft Article 7. Yet, as the fifth report notes, many of those laws are only applicable to the surrender of persons to the International Criminal Court and are not broader in nature. ${ }^{164}$ Indeed, the report lists just five states with broader implementing statutes. ${ }^{165}$

Seventh, the report seems to avoid the implications of fairly consistent case law at the international level that rejects exceptions to immunity for foreign state officials. ${ }^{166} \mathrm{With}$ respect to the International Court of Justice, the Arrest Warrant judgment rejected such exceptions, albeit in the context of immunity of a sitting foreign minister. ${ }^{167}$ The Jurisdictional Immunities of the State judgment also rejected such exceptions, albeit in the context of state immunity. ${ }^{168}$ The reasoning of those decisions would seem to cut against the idea of exceptions to immunity for state officials based on specific crimes, especially given the Court's emphasis on the procedural nature of immunity, in comparison with the substantive crime alleged (even when the crime

\footnotetext{
${ }^{159}$ Ultimately, this analogous exception to immunity from criminal jurisdiction is extremely broad in exposing state officials to local criminal jurisdiction. The exception apparently covers not just a foreign state official who allegedly engages in espionage, hacks into a database over the Internet, sexually assaults a maid in a hotel, or mistreats a nanny, but also a foreign state official who is alleged to have defamed another person, failed to pay parking tickets, written graffiti on a wall, and so on. In other words, it basically exposes the official to the possibility of a criminal prosecution at any time that he or she travels to a foreign state, for any possible allegation of criminal activity under that state's national law.

${ }^{160}$ See id. at 37-38, 41, 89-90, paras. 80, 82, 93, 228 (brief mention).

${ }^{161} I d$. at 26, para. 45.

${ }^{162}$ It should be noted that, during an international armed conflict, international law provides no immunity to state officials in the custody of the enemy belligerent with respect to alleged violations of the law of war or acts of unprivileged belligerency.

163 Jurisdictional Immunities, supra note 133, paras. 65-79.

${ }^{164}$ Fifth Report on Immunity of State Officials, supra note 117, at 30-31, para. 59.

${ }^{165} I d$. at 30, para. 58 (listing Burkina Faso, the Comoros, Ireland, Mauritius, and South Africa).

${ }^{166} I d$. at 31-45, paras. 60-108.

${ }^{167}$ See Arrest Warrant, supra note 133, para. 78(2).

${ }^{168}$ See Jurisdictional Immunities, supra note 133, para. 139.
} 
entails serious violations of human rights). ${ }^{169}$ Indeed, the Court observed in the Jurisdictional Immunities of the State case that "customary international law does not treat a State's entitlement to immunity as dependent upon the gravity of the act of which it is accused or the peremptory nature of the rule which it is alleged to have violated." ${ }^{170}$ In the same case, the Court observed that a logical problem arises with predicating a denial of immunity upon the gravity of the act alleged, since, at the time the immunity is denied, no such act has yet been proven. ${ }^{171}$ Such observations appear to be influencing civil actions against state officials at the national level. ${ }^{172}$

The Court in the Jurisdictional Immunities of the State case did not address immunity of state officials, ${ }^{173}$ but the Court is often cautious in confining itself to the facts and law before it. The issue for the Commission concerns the implications of the Court's judgment, which seem to run contrary to the proposed draft Article 7. Likewise, the European Court of Human Rights has systematically rejected such exceptions, albeit in the context of civil actions brought on the basis of a right of access to a court. These decisions were not unanimous, ${ }^{174}$ and they did not concern criminal prosecutions, but they, too, seem to run contrary to the proposed draft Article 7.

The report relies in part on the Blaškić case, ${ }^{175}$ which was decided in 1997, relatively early in the jurisprudence of the International Criminal Tribunal for the Former Yugoslavia (ICTY), and which addressed the ability of the ICTY to subpoena state officials, not the ability of a state to exercise jurisdiction over a foreign state official. In fact, international criminal tribunals do not seem to have taken a position that exceptions to immunity exist in national courts, other than for the purpose of cooperation with the court or tribunal itself. ${ }^{176}$ Indeed, such tribunals seem to recognize the difference between the two, sometimes noting that "national

\footnotetext{
${ }^{169}$ Fifth Report on Immunity of State Officials, supra note 117, at 36-37, paras. 75, 78 ("The rules of State immunity are procedural in character and are confined to determining whether or not the courts of one State may exercise jurisdiction in respect of another State. They do not bear upon the question whether or not the conduct in respect of which the proceedings are brought was lawful or unlawful. . ..”).

170 Jurisdictional Immunities, supra note 133, para. 84.

${ }^{171} I d$., para. 82 ("At the outset, however, the Court must observe that the proposition that the availability of immunity will be to some extent dependent upon the gravity of the unlawful act presents a logical problem. Immunity from jurisdiction is an immunity not merely from being subjected to an adverse judgment but from being subjected to the trial process. It is, therefore, necessarily preliminary in nature. . . If . . . the mere allegation that the State had committed such wrongful acts were to be sufficient to deprive the State of its entitlement to immunity, immunity could, in effect be negated simply by skilful construction of the claim.").

${ }^{172}$ For example, see the Canadian Supreme Court's 2014 decision in Kazemi Estate v. Islamic Republic of Iran, [2014] SCC 62 (Can.), a civil case against Iranian officials (and Iran) for torture. The Supreme Court upheld immunity, citing the conclusion of the International Court of Justice (ICJ) in Jurisdictional Immunities that immunity is a procedural norm that is not superseded by a substantive norm of jus cogens. Id., para. 204.

${ }^{173}$ One of the cases in Italian courts noted by the ICJ concerned a claim against a former German official, see Jurisdictional Immunities, supra note 133, para. 29, but Germany's claims before the ICJ focused on civil claims against the Federal Republic of Germany itself.

${ }^{174}$ Though downplaying the majority views, the fifth report gives some weight to dissenting opinions in these cases. See, e.g., Fifth Report on Immunity of State Officials, supra note 117, at 33-35, 40-41, paras. 68-70, 92.

${ }^{175}$ Id. at 42-43, para. 98 (citing Prosecutor v. Blaškić, No. IT-95-14-AR 108bis, Judgement on the Request of the Republic of Croatia for Review of the Decision of Trial Chamber II of 18 July 1997, para. 41(2) (Oct. 29, 1997)).

${ }^{176}$ Id. at 43, paras. 99-100.
} 
authorities might use prosecutions to unduly impede or limit a foreign state's ability to engage in international action," whereas such a risk "does not arise with international courts and tribunals, which are "totally independent of states and subject to strict rules of impartiality.",177

Eighth, the report provides a detailed but ultimately questionable assessment of what is happening in the case law at the national level, ${ }^{178}$ at least if the conclusion is that a "majority trend is to accept the existence of certain limitations and exceptions to [immunity ratione materiae]."179 One problem, as previously noted, is that there is no demonstration of a "trend" from one point in time to another. A second problem is that the analysis tends to obscure the number of cases at issue. The report appears to identify just eleven cases over the past fifty years where a national court denied immunity ratione materiae to a foreign state official in a criminal case involving the alleged commission of an international crime. ${ }^{180}$ Of those eleven cases, nine were in Europe, one in Israel, and one in Chile. Such evidence is neither "widespread" nor "representative," if the objective is to identify existing customary international law. ${ }^{181}$ Similarly, the report mentions just three cases where a national court purportedly denied immunity ratione materiae to a foreign state official in a criminal case involving alleged corruption. ${ }^{182}$ Of those

\footnotetext{
${ }^{177}$ E.g., Prosecutor v. Al Bashir, Case No. ICC-02/05-01/09, Decision Pursuant to Article 87(7) of the Rome Statute on the Failure by the Republic of Malawi to Comply with the Cooperation Requests Issued by the Court with Respect to the Arrest and Surrender of Omar Hassan Ahmad Al Bashir, para. 34 (Dec. 12, 2011), at http://www.icccpi.int/iccdocs/doc/doc1287184.pdf (citing ANTONIO CASSESE, INTERNATIONAL CRIMINAL LAW 312 (2d ed. 2008)). ${ }_{178}$ Fifth Report on Immunity of State Officials, supra note 117, at 46-54, paras. 114-22.

${ }^{179} I d$. at 53-54, para. 121.

${ }^{180}$ Id. at 48, para. 114 n.230 (listing Regina v. Bow St. Metro. Stipendiary Magistrate, ex parte Pinochet Ugarte (No. 3), [2000] 1 A.C. 147 (H.L.) (appeal taken from Eng.); Re Pinochet, Tribunal de Premième Instance [Court of First Instance] Brussels, Nov. 6, 1998, 119 ILR 345 (Belg.); In re Hussein, Oberlandesgericht [Higher Regional Court] Cologne, May 16, 2000, No. 2 Zs 1330/99; In re Bouterse, Hof Amsterdam, Nov. 20, 2000, NJ 2001, 51, Eng. trans. at 2001 Neth. Y.B. INT'L L. 266, aff'd, Hoge Raad [Supreme Court], Sept. 18, 2001, NJ 2002, 59, Eng. trans. at 2001 NeTH. Y.B. INT'L L. 282; H.S.A. v. S.A. (Ariel Sharon), Cour de cassation, Feb. 12, 2003, No. P.02.1139.F, 127 ILR 110, 42 ILM 596 (2003) (Belg.); Peru v. Fujimori, Corte Suprema de Justicia [Supreme Court], July 11, 2007, No. 5646-05 (Chile); H v. Public Prosecutor, Hoge Raad, July 8, 2008, No. 07/10063 (E), InT'L L. DOMESTIC CTS. [ILDC] 1017 (Neth.); Lozano v. Italy, Corte suprema di cassazione, sez, un., July 24, 2008, No. 31171/2008, ILDC 1085 (It.); A. v. Office of the Public Prosecutor, Bundesstrafgericht [Federal Criminal Court], July 25, 2012, No. BB.2011.140 (Switz.); FF v. Director of Public Prosecutions (Prince Nasser case), [2014] EWHC (Admin) 3419 (Eng.)); id. at 50, para. 115 n.234 (listing Eichmann, supra note 128).

The only other criminal case cited in support of withholding immunity ratione materiae for "international crimes" is United States v. Noriega, 117 F.3d 1206 (11th Cir. 1997), a case that concerned U.S. drug trafficking laws. See Fifth Report on Immunity of State Officials, supra note 117, at 52, para. 120 n.243. Additional cases cited earlier, $i d$. at 50, para. $114 \mathrm{n} .233$, apparently did not involve any issue of claimed immunity. Other German cases are cited, $i d$. at 50, para. $115 \mathrm{n} .236$, and note that "immunity is not applicable based on the fact that the State of the official no longer exists and that, therefore, the accused no longer has the status of [an] official."

${ }^{181}$ For the Commission's formulation of the required practice when identifying customary international law, see draft Conclusion 8(1) of the draft conclusions on identification of customary international law, 2016 Report, supra note 1, at 94 ("The relevant practice must be general, meaning that it must be sufficiently widespread and representative, as well as consistent.").

${ }^{182}$ Fifth Report on Immunity of State Officials, supra note 117, at 49 n.231 (citing in part Adamov v. Fed. Office of Justice, Tribunal penale federale, Dec. 22, 2005, No 1A 288/2005, ILDC 339 (Switz.)); Fujimori, supra note 181; Nguema Obiang Mangue, Cour d'appel Paris, June 13, 2013 (Fr.)). These same three "corruption" cases are also cited later in this report as speaking to the denial of immunity of state officials "in the context of criminal
} 
cases, two were in Europe and one in Chile. Given that a comparable number of national court cases deny immunity ratione materiae to a foreign state official in a criminal case relating to terrorism or sabotage - three in total ${ }^{183}$ — then, on this methodology, the crime of terrorism would seem to warrant its own exception in draft Article 7. A third problem is that several cases cited in support of an exception for immunity ratione materiae actually involved no prosecution of a state official, such Germany's In re Hussein case, ${ }^{184}$ or were set aside by a higher court, such as the Netherlands' Bouterse case. ${ }^{185}$ A final problem is the assertion that only a "small number of cases" have granted immunity ratione materiae for alleged serious international crimes, when many such cases seem to exist, especially if one looks at both criminal and civil cases. ${ }^{186}$

In any event, what may get lost in the discussion is the report's own recognition that case law on immunity ratione materiae is "less uniform" than case law on immunity ratione personae, ${ }^{187}$ meaning that some cases involving immunity ratione materiae uphold immunity, while other cases do not. Indeed, the report itself points out that "there are very few national court decisions in which immunity was withheld in connection with the commission of any of the established international crimes." 188 Further, when the cases are broken down into the different categories of crimes - cases withholding immunity ratione materiae for genocide, cases withholding such immunity for crimes against humanity, and so on- the numbers look even more sparse.

Finally, though perhaps an insurmountable problem, a thorough methodology would not look solely at cases that have worked their way into the national court system but would also examine whether and why national prosecutors have not pursued prosecutions in the first place. Situations where such prosecutors do not pursue a criminal case due to a belief of immunity, which may occur with considerable frequency, simply do not turn up by analyzing the case law.

The debate at the sixty-ninth session may ultimately lead to the adoption by the Commission of a draft article for this topic on limitations and exceptions; if so, such a draft article likely will reflect an effort at progressive development of the law. The special rapporteur has indicated a desire to submit a sixth report at that session on procedural aspects of immunity of state officials from foreign criminal jurisdiction, ${ }^{189}$ which may assist in addressing concerns

proceedings," along with a fragmentary reference to a U.S. case. $I d$. at 90, para. 230 n.352. The U.S. case, best cited as Doe I v. Li Qui, 349 F.Supp.2d 1258 (N.D. Cal. 2004), is neither a corruption case nor a criminal law case.

${ }^{183}$ Fifth Report on Immunity of State Officials, supra note 117, at 49 n.232 (citing DC 10 UTA, Cour d'assises [court of original jurisdiction] Paris, Mar. 10, 1999 (Fr.); R. v. Mafart (Rainbow Warrior case), [1985] NZHC 243, 74 ILR 241 (1994) (N.Z.); Association des familles des victimes du Joola, Cour de cassation, Jan. 19, 2010, No. 0984818 (Fr.), available at https://www.legifrance.gouv.fr/affichJuriJudi.do?idTexte=JURITEXT000021729943).

${ }^{184} \mathrm{Id}$. at 48, para. 114 n.230 (citing Hussein, supra note 181).

${ }^{185} I d$. (citing Bouterse, supra note 181).

${ }^{186}$ See cases cited at $i d$. at 51-53, paras. 118-20 nn.239-40, 244.

${ }^{187} \mathrm{Id}$. at $48-50$, para. 114 .

${ }^{188}$ Id. at 87, para. 220.

${ }^{189}$ Id. at 95, para. 249. 
about opening the door to politically motivated investigations and prosecutions of foreign state officials.

\section{Provisional Application of Treaties}

The Commission considered the fourth report on the provisional application of treaties by the special rapporteur, Juan Manuel Gómez-Robledo (Mexico), which proposed one further draft guideline for this topic, draft Guideline 10, on the relationship of internal law to the provisional application of a treaty. ${ }^{190}$ After debate in the plenary, the proposed guideline was sent to the drafting committee, ${ }^{191}$ which already had several guidelines before it from the prior session that had not yet been provisionally adopted. ${ }^{192}$

At present, none of the draft guidelines (with commentary) has been adopted by the Commission. The first three draft guidelines were provisionally adopted in the drafting committee in the sixty-seventh session. ${ }^{193}$ An additional five draft guidelines - draft Guidelines $4,6,7,8$, and 9 -were provisionally adopted in the drafting committee during the sixty-eighth session and state as follows:

Draft guideline 4

Form

In addition to the case where the treaty so provides, the provisional application of a treaty or part of a treaty may be agreed through:

(a) a separate agreement; or

(b) any other means or arrangements, including a resolution adopted by an international organization or at an intergovernmental conference.

Draft guideline 6

Commencement of provisional application

\footnotetext{
${ }^{190}$ International Law Commission, Fourth Report on the Provisional Application of Treaties, at 38, para. 179, UN Doc. A/CN.4/699 (June 23, 2016) (prepared by Special Rapporteur Juan Manuel Gómez-Robledo) [hereinafter Fourth Report on Provisional Application of Treaties]. The addendum to the report, UN Doc. A/CN.4/699/Add.1 (June 23, 2016), addresses examples of recent European Union practice on provisional application of agreements with third states.

1912016 Report, supra note 1, at 365, para. 256.

${ }^{192}$ For discussion of prior work on this topic, see Murphy, Sixty-Fourth Session, supra note 2, at 171-73; Murphy, Sixty-Fifth Session, supra note 2, at 53-54; Murphy, Sixty-Sixth Session, supra note 2, at 143-44; Murphy, SixtySeventh Session, supra note 2, at 842-43.

${ }^{193}$ For the text of the draft guidelines, see 2016 Report, supra note 1, at 365, para. 257 n.1454.
} 
The provisional application of a treaty or a part of a treaty, pending its entry into force between the States or international organizations concerned, takes effect on such date, and in accordance with such conditions and procedures, as the treaty provides or as are otherwise agreed.

Draft guideline 7

Legal effects of provisional application

The provisional application of a treaty or a part of a treaty produces the same legal effects as if the treaty were in force between the States or international organizations concerned, unless the treaty provides otherwise or it is otherwise agreed.

Draft guideline 8

Responsibility for breach

The breach of an obligation arising under a treaty or a part of a treaty that is provisionally applied entails international responsibility in accordance with the applicable rules of international law.

Draft guideline 9

Termination upon notification of intention not to become a party

Unless the treaty otherwise provides or it is otherwise agreed, the provisional application of a treaty or a part of a treaty with respect to a State or international organization shall be terminated if that State or international organization notifies the other States or international organizations between which the treaty or a part of a treaty is being applied provisionally of its intention not to become a party to the treaty. ${ }^{194}$

In addition, as proposed by the special rapporteur, draft Guideline 10 on "Internal law and the observation of provisional application of all or part of a treaty," states:

A State that has consented to undertake obligations by means of the provisional application of all or part of a treaty may not invoke the provisions of its internal law as justification for non-compliance with such obligations. This rule is without prejudice to article 46 of the 1969 Vienna Convention. ${ }^{195}$

\footnotetext{
${ }^{194} I d$. at 365-66, para. 257 n. 1454.

${ }^{195}$ Fourth Report on Provisional Application of Treaties, supra note 190, at 38.
} 
This draft guideline has not yet been provisionally adopted by the drafting committee but will be addressed (along with draft Guideline 5, which relates to termination of the obligation to apply a treaty provisionally) at the next session.

When addressing draft Guideline 10, three different scenarios should be considered concerning the relationship of internal law to an agreement to apply a treaty provisionally. The first scenario relates to an agreement on provisional application that itself makes reference to internal law; in such a situation, internal law is relevant for understanding the scope of the agreement on provisional application. Such an agreement may be seen in Article 45(1) of the Energy Charter Treaty, ${ }^{196}$ which was at issue with respect to the tribunal's jurisdiction in the Yukos arbitration, ${ }^{197}$ and more recently in related national proceedings. ${ }^{198}$ This scenario has no connection to the issue of whether a state can plead its internal law so as to escape from an international obligation; rather, it concerns the nature of the international obligation itself.

The second scenario relates an agreement on provisional application that is silent with respect to internal law, but a state seeks to argue that its consent to the agreement was invalid because of a provision of its internal law regarding competence to conclude international agreements. This scenario is analogous to the use of internal law under VCLT Article 46 to declare invalid a treaty that is in force. ${ }^{199}$ Of course, the ability of a state to escape from an agreement to apply a treaty provisionally by mere notification to the other parties, as permitted under VCLT Article 25(2), ${ }^{200}$ usually makes it unnecessary for the state to invoke internal law for this purpose. The issue may be relevant, however, if the objective is to establish that the agreement was void ab initio, in which case no breach of the agreement could have occurred for which reparation is due. ${ }^{201}$

The third scenario relates to an agreement on provisional application that is silent with respect to internal law, but a state seeks to invoke its internal law as justification for its failure to

\footnotetext{
${ }^{196}$ Energy Charter Treaty, Art. 45(1), Dec. 17, 1994, 2080 UNTS 95, 34 ILM 360 (1995) (“Each signatory agrees to apply this Treaty provisionally pending its entry into force for such signatory in accordance with Article 44, to the extent that such provisional application is not inconsistent with its constitution, laws or regulations.").

${ }^{197}$ See Yukos Universal Ltd. v. Russian Federation, PCA Case No. AA 227, Interim Award on Jurisdiction and Admissibility, para. 415 n.100 (Nov. 30, 2009), available at http://www.italaw.com/documents/YULvRussianFederation-InterimAward-30Nov2009.pdf.

${ }^{198}$ See Russian Fed'n v. Veteran Petroleum Ltd., Rechtbank Den Haag [Hague District Court], Apr. 20, 2016, Nos. C/09/477160/HA ZA 15-1, C/09/477162/HA ZA 15-2, C/09/481619/HA ZA 15-112 (Neth.), available at http://uitspraken.rechtspraak.nl/inziendocument?id=ECLI:NL:RBDHA:2016:4230.

${ }^{199}$ VCLT Article 46 indicates in part that a "State may not invoke the fact that its consent to be bound by a treaty has been expressed in violation of a provision of its internal law regarding competence to conclude treaties as invalidating its consent unless that violation was manifest and concerned a rule of its internal law of fundamental importance." VCLT, supra note 60, Art. 46, para. 1.

${ }^{200}$ VCLT Article 25(2) provides: "Unless the treaty otherwise provides or the negotiating States have otherwise agreed, the provisional application of a treaty or a part of a treaty with respect to a State shall be terminated if that State notifies the other States between which the treaty is being applied provisionally of its intention not to become a party to the treaty." VCLT, supra note 60 , Art. 25, para. 2.

${ }^{201}$ See 1 The Vienna Conventions on the LaW OF Treaties: A Commentary 646 (Oliver Corten \& Pierre Klein eds., 2011) [hereinafter VIENNA CONVENTIONS].
} 
perform its international obligations. This scenario is analogous to the use of internal law to justify nonperformance of a treaty that is in force; in that situation, VCLT Article 27 provides that a "party [to a treaty] may not invoke the provisions of its internal law as justification for its failure to perform a treaty." 202 Here again, even though mere notification to the other parties allows the state to escape from an agreement to apply the treaty provisionally, the issue may be relevant if the objective of the state is to establish that no breach based on nonperformance under the treaty has occurred for which reparation is due. ${ }^{203}$

\section{ILC ELECTION IN 2016 AND FUTURE WORK}

The sixty-eighth session was the last session of the current quinquennium of the Commission. A new Commission of thirty-four members will be elected by the UN General Assembly on November 3, 2016, to serve from 2017 until 2021.

During the next quinquennium, the Commission may decide to move new topics onto its agenda. In that regard, during the sixty-eighth session, the Commission placed two new topics on its long-term work program (thus signaling that they might be moved to the active agenda): (1) the settlement of international disputes to which international organizations are parties; $;^{204}$ and (2) succession of states in respect of state responsibility. ${ }^{205}$

\footnotetext{
${ }^{202}$ VCLT, supra note 60, Art. 27.

${ }^{203}$ VIENNA CONVENTIONS, supra note 202, at 646.

2042016 Report, supra note 1, at 387, Annex A.

${ }^{205}$ Id. at 400, Annex B.
} 